\title{
Analisis Peningkatan Sikap Remaja dalam Pencegahan HIV / AIDS
}

Shofura Nida Khansa, Muhammad Ali Sodik

IIK STRADA INDONESIA

shofuranida2001@gmail.com, alisodik2012@gmail.com

\begin{abstract}
Abstrak
Pergaulan bebas pada remaja dapat kembali mempermudah risiko tertular penyakit menular seksual seperti HIV dan AIDS. Hal ini dikarenakan remaja belum memiliki pengetahuan yang benar tentang kesehatan reproduksi dan seks. Informasi yang didapat biasanya berasal dari teman atau media, yang biasanya kurang atau bahkan tidak akurat. Tujuan penelitian ini adalah untuk mengetahui analisis peningkatan sikap remaja dalam pencegahan HIV / AIDS melalui pendidikan Health Award dengan metode peer education pada remaja di kota Kediri. Hasil penelitian menunjukkan bahwa sebagian besar responden memiliki sikap pencegahan HIV / AIDS sebelum penyuluhan kesehatan berada pada kategori negatif, 100 responden $(62,5 \%)$ sedangkan mayoritas responden memiliki sikap pencegahan HIV / AIDS setelah penyuluhan kesehatan dalam kategori positif.
\end{abstract}

Kata Kunci: Sikap Remaja, Pencegahan, Sikap, HIV / AIDS.

\section{Latar Belakang}

Masa remaja sangat erat kaitannya dengan perkembangan psikis pada periode pubertas dan diiringi dengan perkembangan seksual. Usia remaja adalah usia yang sedang mengalami peningkatan kerentanan terhadap berbagai ancaman risiko kesehatan terutama yang berkaitan dengan kesehatan seksual dan reproduksi termasuk peningkatan ancaman dari HIV/AIDS. Acquired immunodeficiency syndrome (AIDS) adalah sindroma dengan gejala penyakit infeksi oportunistik atau kanker tertentu akibat menurunnya sistem kekebalan tubuh oleh infeksi Human Immunodeficiency Virus(HIV).

Jumlah kasus HIV/AIDS berfluktuatif setiap tahunnya. Pada akhir tahun 2016 jumlah kasus HIV/AIDS mengalami kenaikan dengan jumlah penderita di Indonesia dilaporkan sebanyak 41.250 kasus HIV dan 7.491 kasus AIDS. Jumlah AIDS yang dilaporkan menurut kelompok pekerjaan/status Oktober-Desember 2016 jumlah kasus AIDS pada anak sekolah/mahasiswa sebanyak 130 kasus, hampir sama dengan kasus pada kelompok penjaja seks. Kasus HIV paling banyak ditemukan pada penduduk usia 20-29 tahun. Apabila AIDS tertinggi adalah kelompok umur 20-29 tahun, ini berarti jika sejak terinfeksi sampai masuk ke kondisi AIDS lamanya 5 tahun, maka usia terendah saat terinfeksi sekitar 15-24 tahun. 
Informasi tentang HIV relatif lebih banyak diterima oleh remaja, meskipun hanya $9,9 \%$ remaja perempuan dan $10,6 \%$ laki-laki yang memiliki pengetahuan komprehensif mengenai HIV/AIDS. Pengetahuan yang baik akan mendukung sikap yang baik pula. Adanya suatu pengetahuan tentang HIV/AIDS dapat mempengaruhi siswa untuk bersikap sesuai pengetahuan yang didapat. Remaja yang tidak memiliki cukup pengetahuan, tidak bisa memahami perilaku berisiko yang dapat meningkatkan kemungkinan infeksi HIV. Remaja dengan tingkat sikap positif yang baik memiliki tingkat perilaku yang baik. Sikap sangat berkaitan erat dengan tingkat pengetahuan suatu individu. Sikap seseorang terhadap suatu objek menunjukkan tingkat pengetahuan orang tersebut terhadap suatu objek. Berdasarkan teori adaptasi apabila tingkat pengetahuan baik dapat mendorong suatu individu memiliki perilaku yang baik. Keterpaparan sumber informasi berpengaruh terhadap perilaku pencegahan HIV/AIDS hal ini membuktikan bahwa keterpaparan sumber informasi sangat berperan dalam perubahan perilaku pencegahan HIV/AIDS.

\section{Rumusan Masalah}

Sikap seseorang terhadap suatu objek menunjukkan tingkat pengetahuan orang tersebut terhadap suatu objek. Berdasarkan teori adaptasi apabila tingkat pengetahuan baik dapat mendorong suatu individu memiliki perilaku yang baik. Pada program kurikulum pendidikan SMA sudah menerapkan pendidikan tentang HIV/AIDS pada mata pelajaran biologi dan penjasorkes (pendidikan jasmani, olahraga, dan kesehatan) serta mendapatkan penyuluhan tentang HIV/AIDS setiap tahunnya dari Puskesmas Sleman pada saat Masa Orientasi Siswa (MOS). Adanya penyuluhan dan pendidikan ini diharapkan menjadi salah satu upaya untuk mencegah kejadian HIV/AIDS pada remaja. Berdasarkan uraian latar belakang tersebut, maka dapat dirumuskan pertanyaan penelitian "Apa sajakah faktor-faktor yang mempengaruhi perilaku remaja terhadap pencegahan HIV/AIDS pada Tahun 2018?"

\section{Tinjauan Pustaka}

HIV, singkatan dari Human Immunodeficiency Virus, adalah virus khusus sebagai penyebab penyakit berat yang umum dikenal sebagai AIDS (Acquired Immunedeficiency Syndrome). AIDS merupakan fase terminal (akhir) dari infeksi HIV. Virus tersebut mengancam nyawa karena menyerang sistem yang membahayakan tubuh dan kemampuan tubuh untuk menyerang infeksi dan penyakit. Orang yang telah terinfeksi HIV dalam beberapa tahun pertama belum menunjukkan gejala apapun, secara fisik kelihatan tidak berbeda dengan orang lain. Namun, dia sudah bisa menularkan HIV pada orang lain.

Fase perkembangan perjalanan HIV di dalam tubuh manusia secara umum dibagi dalam 4 fase, yaitu Fase Window Period (Periode Jendela), Fase Asymptomatic (Tanpa Gejala), Fase Symptomatic (Bergejala), dan Fase AIDS. Ada beberapa upaya yang dapat dilakukan seseorang dalam mencegah tertularnya HIV, seperti berikut:

1) Menghindari seks bebas

2) Tidak menggunakan jarum suntik bergatian 
3) Menggunakan kondom ketika berhubungan seksual

4) Melakukan vaksin hepatitis A dan hepatitis B, serta melakukan tes HIV secara teratur

5) Pre-exposure prophylaxis (PrEP)

Saat ini, belum ditemukan obat yang dapat menghilangkan HIV/AIDS dari tubuh manusia. Obat yang ada hanya menghambat virus (HIV), tetapi tidak dapat menghilangkan HIV di dalam tubuh. Obat tersebut adalah antiretroviral (ARV). Menurut data FKUI/RSCM tahun 2010, lebih dari 250 ODHA (Orang Dengan HIV dan AIDS) yang minum ARV secara rutin setiap hari, setelah 6 bulan jumlah viral load-nya (banyaknya jumlah virus dalam darah) tidak terdeteksi. Meski sudah tidak terdeteksi, pemakaian ARV tidak boleh dihentikan karena dalam waktu dua bulan akan kembali ke kondisi sebelum diberi ARV. Ketidaktaatan dan ketidakteraturan dalam menerapkan terapi ARV adalah alasan utama mengapa penderita gagal memperoleh manfaat dari penerapan ARV.

Terdapat bermacam-macam alasan atas sikap tidak taat dan tidak teratur untuk penerapan pengobatan tersebut, diantaranya karena adanya efek samping/dampak pengobatan tidak bisa ditolerir (diare, tidak enak badan, mual, dan lelah), terapi antiretrovirus sebelumnya yang tidak efektif, infeksi HIV tertentu yang resisten obat, tingkat kepatuhan pasien, dan kesiapan mental pasien untuk memulai perawatan awal. Tanpa terapi antiretrovirus, rata-rata lamanya perkembangan infeksi HIV menjadi AIDS ialah 9-10 tahun dan ratarata waktu hidup setelah mengalami AIDS hanya sekitar 9,2 bulan. Namun demikian, laju perkembangan penyakit ini pada setiap orang sangat bervariasi, yaitu dari 2 minggu sampai 20 tahun.

\section{Pembahasan}

Jenis kelamin dan jurusan pendidikan termasuk dalam faktor predisposisi (Presdisposing Factors) dalam Theory PRECEDE-PROCEED Model pada bagian karakteristik individu. Pada teori model perubahan perilaku PRECEDE-PROCEED yang dikembangkan oleh Lawrence Green dan M. Kreuter (2005) menyatakan bahwa perilaku kesehatan dipengaruhi oleh faktor-faktor individu maupun lingkungan. (Fertman CI, Allensworth DD, 2010). Tidak terdapat hubungan yang signifikan antara jenis kelamin dengan perilaku remaja terhadap pencegahan HIV/AIDS. Uraian tersebut sejalan dengan penelitian yang telah dilakukan oleh Aung Zaw (2013) menyatakan bahwa tidak ada hubungan yang signifikan antara jenis kelamin dengan KAP (Knowledge, Attitude, Practice).

Sexual cognitions pada laki-laki lebih besar dibandingkan perempuan sehingga remaja laki-laki cenderung memikirkan lebih banyak tentang hal-hal seksual dibandingkan perempuan. Menurut Mahmudah (2016) mengatakan bahwa laki-laki memiliki peluang lebih besar untuk berperilaku seksual berisiko dibandingkan perempuan. Menurut Boynaturally (2010, dalam Sofni, LM., 2015) menjelaskan bahwa hal ini dikarenakan perempuan lebih sadar dan perhatian terhadap kesehatan dirinya dibandingkan pada laki-laki. 
Tidak ada hubungan yang bermakna antara tingkat pendidikan dengan perilaku pencegahan penularan HIV/AIDS oleh ODHA usia reproduksi. Uraian ini juga sejalan dengan Rahmawan, E.F. (2013) menyatakan bahwa tidak terdapat perbedaan yang terlalu signifikan antara minat siswa kelas IPA dan kelas IPS terhadap pembelajaran pendidikan jasmani, olahraga, dan kesehatan di SMA Negeri 1 Sidoarjo. Berdasarkan perbedaan cara berfikir siswa kelas IPA dan kelas IPS pembelajaran penjasorkes bisa digunakan sebagai sarana untuk menunjang siswa mengembangkan cara berfikir ilmiah dan alamiah.

Pengetahuan atau ranah kognitif merupakan domain yang sangat penting dalam membentuk tindakan seseorang. Pengetahun merupakan faktor terpenting dalam pembentukan perilaku individu sehingga positif dan negatifnya perilaku seseorang sangat dipengaruhi oleh tingkat pengetahuan. Sikap merupakan salah satu faktor yang mempengaruhi perilaku remaja terhadap pencegahan HIV/AIDS. Faktor lain yang mempengaruhi perilaku remaja terhadap pencegahan HIV/AIDS adalah sumber informasi. Sumber informasi yang cukup memberikan pengetahuan yang baik kepada seseorang. Namun, meskipun pengetahuan yang baik, tetapi seseorang cenderung tetap melakukan tindakan yang berpotensi membuat tertular HIV. Hal ini disebabkan oleh tidak adanya kesadaran dan rasa takut akan terjangkit virus HIV/AIDS.

Secara keseluruhan faktor yang paling mempengaruhi perilaku remaja terhadap pencegahan HIV/AIDS berdasarkan hasil analisis uji multivariat menunjukkan remaja yang memiliki sikap terhadap pencegahan HIV/AIDS pada kategori mendukung akan berpeluang memiliki perilaku positif 4,4 kali lebih besar dibandingkan remaja yang memiliki sikap terhadap pencegahan HIV/AIDS pada kategori tidak mendukung. Hal ini sesuai pendapat Simon Morton, yang menyatakan bahwa pengetahuan merupakan mediator perubahan perilaku dan variabel yang secara langsung mempengaruhi perilaku adalah sikap.

\section{Kesimpulan}

Berdasarkan pembahasan diatas, maka dapat ditarik kesimpulan, tidak terdapat hubungan yang signifikan antara jenis kelamin dengan perilaku remaja terhadap pencegahan HIV/AIDS. Sexual cognitions pada laki-laki lebih besar dibandingkan perempuan sehingga remaja laki-laki cenderung memikirkan lebih banyak tentang hal-hal seksual dibandingkan perempuan. Tidak ada hubungan yang antara tingkat pendidikan dengan perilaku pencegahan penularan HIV/AIDS oleh ODHA usia reproduksi. Sikap merupakan salah satu faktor yang mempengaruhi perilaku remaja terhadap pencegahan HIV/AIDS. Faktor lain yang mempengaruhi perilaku remaja terhadap pencegahan HIV/AIDS adalah sumber informasi. Sumber informasi paling banyak pada penelitian ini bersumber dari media elektronik, yaitu televisi dan internet. Tidak ada hubungan antara sumber informasi dengan perilaku remaja terhadap pencegahan HIV/AIDS. Terdapat hubungan antara tingkat pengetahuan dengan perilaku remaja terhadap pencegahan HIV/AIDS. Faktor yang paling 
mempengaruhi perilaku remaja terhadap pencegahan HIV/AIDS adalah variabel sikap terhadap pencegahan HIV/AIDS.

\section{Daftar Pustaka}

Sodik, M. A. (2018). Analisis Peningkatan Sikap Remaja dalam Pencegahan HIV / AIDS melalui Penyediaan Pendidikan Kesehatan dengan Pendidikan Sebaya.

Faktor yang Mempengaruhi Perilaku Remaja Terhadap Pencegahan HIV / AIDS (2018)

Apa itu HIV / AIDS : Gejala, Penyebab, Diagnosis, dan Cara Mengobati https://www.docdoc.com/id/info/condition/hiv-aids

Cara Pencegahan HIV Sejak Dini, Serta Gejala yang Sering Tak Disadari (2019) https://www.liputan6.com/health/read/3919506/cara-pencegahan-hiv-sejak-dini-sertagejala-yang-sering-tak-disadari 